\title{
Production and Characterization of New Fibrinolytic Protease from Mucor subtillissimus UCP 1262 in Solid-State Fermentation
}

\author{
Thiago Pajeú Nascimentoํ, Amanda Emmanuelle Sales², Camila Souza Porto², \\ Romero Marcos Pedrosa Brandão ${ }^{2}$, Galba Maria Campos Takaki ${ }^{3}$, \\ Jose Antônio Couto Teixeira4, Tatiana Souza Porto ${ }^{2,5}$, Ana Lúcia Figueiredo Porto ${ }^{2 *}$ \\ ${ }^{1}$ Center for Biological Sciences, Federal University of Pernambuco, Recife, Brazil \\ ${ }^{2}$ Department of Morphology and Animal Physiology, Federal Rural University of Pernambuco, Recife, Brazil \\ ${ }^{3}$ Center for Research in Environmental Sciences, Catholic University of Pernambuco, Recife, Brazil \\ ${ }^{4}$ Institute for Biotechnology and Bioengineering, Centre of Biological Engineering, University of Minho, Campus \\ of Gualtar, Braga, Portugal \\ ${ }^{5}$ Academic Unit of Garanhuns, Federal Rural University of Pernambuco, Garanhuns, Brazil \\ Email: analuporto@yahoo.com.br
}

Received 14 July 2015; accepted 5 September 2015; published 8 September 2015

Copyright (C) 2015 by authors and Scientific Research Publishing Inc.

This work is licensed under the Creative Commons Attribution International License (CC BY).

http://creativecommons.org/licenses/by/4.0/

c) (i) Open Access

\section{Abstract}

Fibrinolytic enzymes have received attention regarding their medicinal potential for thrombolytic diseases, a leading cause of morbidity and mortality worldwide. Various natural enzymes purified from animal, plant and microbial sources have been extensively studied. The aim of this work was to produce fibrinolytic protease by solid state fermentation using agro industrial substrates. Rhizopus arrhizus var. arrhizus UCP 1295 and Mucor subtillissimus UCP 1262 filamentous fungi species isolated from soil of Caatinga-PE, Brasil, were used as producer microorganisms. Wheat bran was shown to be the best substrate for the production of the enzyme and by using a $2^{3}$ full factorial design the main effects and interactions of the quantity of the substrate wheat bran, moisture and temperature on the fibrinolytic enzyme production and protease were evaluated. The best results for fibrinolytic and protease activities, $144.58 \mathrm{U} / \mathrm{mL}$ and $48.33 \mathrm{U} / \mathrm{mL}$, respectively, were obtained with Mucor subtillissimus UCP 1262 using as culture medium $3 \mathrm{~g}$ wheat bran, $50 \%$ moisture at a temperature of $25^{\circ} \mathrm{C}$ for 72 hours. The optimum temperature for the produced enzyme was $45^{\circ} \mathrm{C}$ and most of its original activity was retained after being subjected to $80^{\circ} \mathrm{C}$ for $120 \mathrm{~min}$. The pro-

\footnotetext{
${ }^{*}$ Corresponding author.
}

How to cite this paper: Nascimento, T.P., Sales, A.E., Porto, C.S., Brandão, R.M.P., Takaki, G.M.C., Teixeira, J.A.C., Porto, T.S. and Porto, A.L.F. (2015) Production and Characterization of New Fibrinolytic Protease from Mucor subtillissimus UCP 1262 in Solid-State Fermentation. Advances in Enzyme Research, 3, 81-91. http://dx.doi.org/10.4236/aer.2015.33009 
tease activity was enhanced by $\mathrm{K}^{+}, \mathrm{Ca}^{+}$and $\mathrm{Mn}^{+}$; but with $\mathrm{Cu}^{+}$there was an inhibition. The specificity to chromogenic substrate and the inhibition by PMSF indicates that it is a chymotrypsin-like serine protease. Presented results suggest that this enzyme produced by solid-state fermentation is an interesting alternative as a candidate for thrombolytic therapy.

\section{Keywords}

\section{Mucor, Enzyme, Protease, Fibrinolytic, Wheat}

\section{Introduction}

About 17.3 million people die each year of cardiovascular disease. It is estimated that in 2030 the number of deaths could reach 23.6 million [1]. Cardiovascular diseases include acute myocardial infarction, ischemic heart disease, valvular heart disease, peripheral vascular disease, arrhythmias, high blood pressure and stroke [2] [3]. These problems are usually caused by accumulation of fibrin (blood clots) that adhere to the blood vessels wall leading to thrombosis [4].

Various thrombolytic agents have been used in the therapeutic treatment of thrombosis, but due to their high cost and hemorrhagic side effects, new sources of these agents have been sought after. Fibrinolytic enzymes produced by microorganisms, have the potential to inhibit blood coagulation and are able to degrade the fibrin. Some potential microorganisms like bacteria of the genus Bacillus, cyanobacteria, fungi, and Streptomyces have been described as sources of fibrinolytic agents [5]-[9].

Filamentous fungi have been shown to be a good choice for the production of fibrinolytic enzymes due to the good production values and easy separation of the enzymes, since most of them are extracellular [10]. The order Mucorales comprising the genus Rhizopus, Mucor, Rhizo-Mucor, Cunninghamella and Absidia is known to demonstrate a potential for production of proteinases with milk clotting activity. The genus Mucor is known as producer of extracellular proteases, amylases and lipases [11].

Among the fermentation processes available for enzyme production by filamentous fungi, the solid-state fermentation (SSF) is highly suitable since the microorganisms grow naturally in solid substrates such as wood, roots, plant leaves, and in the absence of free water. SSF is gaining an increasing interest for enzyme production because it is a low-cost technology; it allows an easy recovery of biomolecules and presents higher yields when compared to submerged fermentation. Also, SSF is an alternative to the use of agro industrial residues as substrate avoiding negative impacts to the environment [12]-[14].

Another advantage to using SSF is preventing negative effect phenomena in the biosynthesis of the enzyme such as catabolite repression by glucose or inhibition of the biosynthesis of amino acids and ammonia [11] [15] [16]. The present study evaluates the production of fibrinolytic protease by Rhizopus arrhizus var. arrhizus UCP 1295 and Mucor subtillissimus UCP 1262 in solid-state fermentation using agroindustrial residues.

\section{Material and Methods}

\subsection{Microorganisms}

Rhizopus arrhizus var. arrhizus UCP 1295 and Mucor subtillissimus UCP 1262 were used. Both were isolated from Caatinga soil, Serra Talhada, PE-Brazil and deposited in the culture collection of the Catholic University of Pernambuco-Brazil. These microorganisms were maintained on Czapek medium (Sucrose $30 \mathrm{~g} / \mathrm{L}$; Sodium nitrate $2 \mathrm{~g} / \mathrm{L}$; Dipotassium phosphate $1 \mathrm{~g} / \mathrm{L}$; Magnesium sulphate $0.5 \mathrm{~g} / \mathrm{L}$; Potassium Chloride $0.01 \mathrm{~g} / \mathrm{L}$; Agar 15.0 $\mathrm{g} / \mathrm{L}$; final $\mathrm{pH}\left(\right.$ at $\left.25^{\circ} \mathrm{C}\right) 7.3 \pm 0.2$; HIMEDIA M075-500G) at $30^{\circ} \mathrm{C}$ for 7 days.

\subsection{Preparation of Inoculum}

The spores were collected of microorganisms by nutrient solution comprised of $0.5 \%(\mathrm{w} / \mathrm{v})$ yeast extract, $1 \%$ $(\mathrm{w} / \mathrm{v})$ glucose and $0.01 \%$ Tween $80(\mathrm{w} / \mathrm{v})$ diluted in sodium phosphate buffer $245 \mathrm{mM}$ and $\mathrm{pH} 7.0$ previously sterilized: The spores were counted in Neubauer chamber to a final concentration of $10^{7}$ spores $/ \mathrm{mL}$. 


\subsection{Selection of the Substrate(s) for the Production of Fibrinolytic Protease by SSF}

Rhizopus arrizus var. arrizus UCP 1295 and Mucor subtillissimus UCP 1262 were inoculated to a final concentration of $10^{7}$ spores/mL in $125 \mathrm{~mL}$ Erlenmeyer flasks, containing $5 \mathrm{~g}$ of substrate: passion fruit peel, corncob, cassava peel, soybeans, Malpighia emarginata seed, wheat bran and citrus pulp with a granulometry between 0.6 to $2.0 \mathrm{~mm}$. (moisture of $40 \%$ ) at $30^{\circ} \mathrm{C}$ for 72 hours. The substrates were dried at $65^{\circ} \mathrm{C}$ until complete dehydration and then stored in plastic containers for further use. For each situation, the amount of produced fibrinolytic protease was evaluated by Fibrinolytic activity.

\subsection{SSF Optimization for the Production of Fibrinolytic Protease}

Experiments were carried out in $125 \mathrm{~mL}$ Erlenmeyer flasks containing the selected substrate(s) autoclaved for $20 \mathrm{~min}$ at $121^{\circ} \mathrm{C}$. The substrate(s) were moistened as needed with nutrient solution and water to reach the desired moisture. A full factorial design $\left(2^{3}\right)$ was used to determine the influence of the parameters: mass of substrate, moisture and temperature (Table 1) on the production of the enzyme. After inoculation, the flasks were incubated $\left(10^{7}\right.$ spores $\left./ \mathrm{mL}\right)$ for 72,96 and 120 hours of fermentation. These parameters were selected according to pre-test.

\subsection{Extract Fibrinolytic Enzymes and Proteases}

Extraction of the enzyme was performed after 72 hours of fermentation. $7.5 \mathrm{~mL}$ of sodium phosphate buffer pH 7 (245 mM) per $1 \mathrm{~g}$ of substrate were added and the flasks were placed in an orbital shaker at $150 \mathrm{rpm}$ for 90 min at room temperature. After this period, the contents were centrifuged at $3500 \mathrm{rpm}$ for $10 \mathrm{~min}$, and the supernatant was used for determination of the enzyme activity.

\subsection{Protease Activity}

The determination of protease activity was done by the method of Ginther [17]. One unit of enzyme activity was defined as the amount of enzyme that produced an increase in the optical density of 0.1 per hour at $420 \mathrm{~nm}$. The experiments were done in duplicate.

\subsection{Fibrinolytic Activity}

The fibrinolytic activity was determined using the spectrophotometric method described by Wang et al. [18]. First, $0.4 \mathrm{~mL}$ of $0.72 \%$ fibrinogen was placed in a test tube with $0.1 \mathrm{~mL}$ of $245 \mathrm{mM}$ phosphate buffer (pH 7) and incubated at $37^{\circ} \mathrm{C}$ for $5 \mathrm{~min}$. Then, $0.1 \mathrm{~mL}$ of a $20 \mathrm{U} / \mathrm{mL}$ thrombin solution was added. The solution was incubated at $37^{\circ} \mathrm{C}$ for $10 \mathrm{~min}, 0.1 \mathrm{~mL}$ of diluted enzyme solution was added, and incubation continued at $37^{\circ} \mathrm{C}$. This solution was again mixed after 20 and $40 \mathrm{~min}$. At $60 \mathrm{~min}, 0.7 \mathrm{~mL}$ of $0.2 \mathrm{M}$ trichloroacetic acid (TCA) was added, and mixed. The reaction mixture was centrifuged at $15,000 \times \mathrm{g}$ for $10 \mathrm{~min}$. Then, $1 \mathrm{~mL}$ of the supernatant was collected and the absorbance at $275 \mathrm{~nm}$ was measured. In this assay, 1 unit (fibrin degradation unit, FU) of enzyme activity is defined as a 0.01-per-minute increase in absorbance at $275 \mathrm{~nm}$ of the reaction solution.

\subsection{Protein Determination}

The protein content was determined by the method described by Bradford [19] using bovine serum albumin (BSA) as a standard. Each experiment was performed in triplicate and the average value was then calculated after correction with the corresponding blank.

Table 1. Levels of the variables studied in a $2^{3}$ complete factorial design for the production of the fibrinolytic proteases.

\begin{tabular}{cccc}
\hline Variables & \multicolumn{3}{c}{ Levels } \\
\cline { 2 - 4 } & Low $(-1)$ & Central $(0)$ & High $(+1)$ \\
\hline Substrate amount (g) & 3 & 5 & 35 \\
Temperature $\left({ }^{\circ} \mathrm{C}\right)$ & 25 & 30 & 50 \\
Moisture $(\%)$ & 30 & 40 & 70 \\
\hline
\end{tabular}




\subsection{Substrate Specificity}

Amidolytic activity was measured spectrophotometrically using the chromogenic substrates: N-Succinyl-AlaAla-Pro-Phe $p$-nitroanilide (S7388 Sigma) and Gly-Arg-p-nitroanilide dihydrochloride (G8148 Sigma). The reaction mixture $(0.8 \mathrm{~mL})$ contained $30 \mu \mathrm{L}$ of enzyme solution, $30 \mu \mathrm{L}$ of chromogenic substrate and $140 \mu \mathrm{L}$ of $20 \mathrm{mM}$ Tris- $\mathrm{HCl}$ (pH 7.4). After incubation for $15 \mathrm{~min}$ at $37^{\circ} \mathrm{C}$, the amount of liberated $p$-nitroaniline (pNA) was calculated by spectrophotometric absorption at $405 \mathrm{~nm}$. One unit of amidolytic activity (AU) was expressed as the number of micro moles of substrate hydrolyzed per minute and per milliliter by the enzyme Kim et al. [20].

\subsection{Effect of Temperature on Protease Activity and Stability}

The temperature effect was determined by incubating the crude extract at temperatures ranging between 10 and $100^{\circ} \mathrm{C}$ for $60 \mathrm{~min}$. To determine the stability to temperature, aliquots were withdrawn every $30 \mathrm{~min}$ for a period of 3 hours. These aliquots were submitted to the determination of protease activity.

\subsection{Effect of Metal Ions on Protease Activity}

The protease activity of the crude extract was evaluated in the presence of metal ions. These ions are described as inhibitors or activators of protease activity. The effect of ionic solutions was evaluated at concentrations of $2.5 \mathrm{mM} ; 5 \mathrm{mM}$ and $10 \mathrm{mM}$. The crude extract was exposed to the following ions: $\mathrm{zinc}\left(\mathrm{Zn}^{+}\right)$, magnesium $\left(\mathrm{Mg}^{+}\right)$, copper $\left(\mathrm{Cu}^{+}\right)$, ferrous $\left(\mathrm{Fe}^{+}\right)$, calcium $\left(\mathrm{Ca}^{+}\right)$, magnesium $\left(\mathrm{Mg}^{+}\right)$, sodium $\left(\mathrm{Na}^{+}\right)$, potassium $\left(\mathrm{K}^{+}\right)$, and cobalt $\left(\mathrm{Co}^{+}\right)$. and incubated at $37^{\circ} \mathrm{C}$ for $60 \mathrm{~min}$. The ions were dissolved in Tris- $\mathrm{HCl} \mathrm{pH} 7.75$ with $150 \mathrm{mM} \mathrm{NaCl}$.

\subsection{Effect of Inhibitors in Protease Activity}

To evaluate the effect of inhibitors on enzyme activity, the crude extract was exposed to the following inhibitors: PMSF (fluoride-methylphenylsulfonyl $\mathrm{C}_{7} \mathrm{H}_{7} \mathrm{FO}_{2} \mathrm{~S}$ ), 2-mercaptoethanol (2-hydroxy1-ethanethiol- $\mathrm{C}_{2} \mathrm{H}_{6} \mathrm{SO}$ ), ethylenediaminetetraacetic-acid (EDTA-acetic- $\mathrm{C}_{10} \mathrm{H}_{16} \mathrm{~N}_{2} \mathrm{O}_{8}$ ), Pepstatin $A$ and Iodoacetic Acid. Incubations were done for $60 \mathrm{~min}$ at $37^{\circ} \mathrm{C}$; the inhibitors were dissolved in according to the protocol provided by Sigma, and the concentration of the solutions was standardized at $5 \mathrm{mM}$.

\subsection{Statistical Analysis}

The effects were evaluated by an analysis of variance with a significance level of $95 \%$ to make estimates of the main and second-order effects a linear, absolute value of the factors in relation to the response variables studied. Statistical analysis of the experimental design was performed using the software Statistical 8.0 [21]. For data analysis, we used the Student $t$ test for independent samples; For the purpose of compare the means of the effect of the inhibitors in the enzymatic activity of the protease. The results were considered statistically significant at $p \leq 0.05$ and was used excel software 2007.

\section{Results and Discussion}

\subsection{Selection of the Substrate for Production of Fibrinolytic Protease}

The production of fibrinolytic protease by Rhizopus arrizus var. arrizus UCP 1295 and Mucor subtillissimus UCP 1262 was carried out using 7 agroindustrial substrates. No growth was observed when passion fruit peel, citrus pulp and Malpighia emarginata seed were used. This phenomenon may be due to low content of protein in these substrates, as described by [22]-[24]. The substrates with a higher protein such as soybeans and wheat bran were those with a higher protease production as can be seen in Table 2. Fibrinolytic activities of $47 \mathrm{U} / \mathrm{mL}$ and $78 \mathrm{U} / \mathrm{mL}$ were obtained using soybeans and wheat bran, respectively, by Mucor subtillissimus UCP 1262; in the Rhizopus arrhizus var. arrhizus UCP 1295 strain were obtained values $39 \mathrm{U} / \mathrm{mL}$ and $58 \mathrm{U} / \mathrm{mL}$ for soybean and wheat bran, respectively.

The maximum protease production was observed when wheat bran was used as substrate. These results are similar to those reported by Ravikumar et al. [25] when producing protease by SSF using Pleurotus sajor-caju with different agricultural products, wheat bran was the best for the production of protease with an activity of 35 $\mathrm{U} / \mathrm{mL}$. 
Table 2. Production of fibrinolytic protease by Rhizopus arrizus var. arrizus UCP 1295 and Mucor subtillissimus UCP 1262 using different substrates in SSF.

\begin{tabular}{ccccccc}
\hline \multirow{2}{*}{ Substrates } & \multicolumn{2}{c}{ FA $(\mathrm{U} / \mathrm{mL})$} & \multicolumn{2}{c}{$\mathrm{U} / \mathrm{gdb}(\mathrm{FA})$} & \multicolumn{2}{c}{ PA (U/mL) } \\
\cline { 2 - 7 } & Mucor & Rhizopus & Mucor & Rhizopus & Mucor & Rhizopus \\
\hline Corncob & 10.81 & 10.47 & 162.15 & 157.05 & 9.87 & 11.76 \\
Cassava peel & 18.24 & 16.42 & 273.60 & 246.30 & 16.10 & 14.54 \\
Soybean & 47.00 & 39.03 & 705.01 & 585.06 & 27.06 & 23.87 \\
Wheat bran & 78.00 & 58.05 & 1170.05 & 870.07 & 38.08 & 30.77 \\
\hline
\end{tabular}

FA: Fibrinolytic Activity; U/gdb: Unit/grams of substrate on a dry basis; PA: Protease activity.

\subsection{Production of Fibrinolytic Protease by SSF}

The results presented for the production fibrinolytic protease by M. subtillissimus UCP 1262 using wheat bran as substrate was performed according to the Table 1 . The highest enzyme production was obtained by using wheat bran as a result of the availability of nutrients for microbial growth. These grains are rich in nutrients such as proteins, lipids, vitamins and functional compounds- wheat brains are not used as food due to its biological unavailability and unpleasant organoleptic nature [26].

Wheat bran also provides compounds, which can induce the production of determined biomolecules [14] [27]. Besides, wheat bran substrate and a simple, consisting of co product of agricultural origin unrefined that contain all the nutrients required for the microorganism growth. Studies by Alves [28] [29] showed protease production by genus Mucor and from the 12 species evaluated; the largest producer was Mucor racemosus Fres. f. chibinensis. In the second study, with 56 isolates of Mucor originating from dung of herbivores, 82\% showed production of enzymes with protease activity. Sathya [30] also obtained extracellular protease production by Mucor circinelloides using agroindustrial substrate by SSF.

Soares et al. [31] using wheat bran as substrate for protease production by the nematophagous fungus Monacrosporium sinense (SF53) by solid-state fermentation, obtained an activity of $38.0 \mathrm{U} / \mathrm{mL}$ at 211 hours of incubation. The highest values of activity protease and fibrinolytic by M. subtillissimus UCP 1262 occurred with 72 hours of fermentation using wheat bran as substrate. These results were obtained with a less fermentation time (72 hours) and greater protease activity $(48.33 \mathrm{U} / \mathrm{mL})$.

Table 3 shows the values of the protease activity and fibrinolytic activity obtained using factorial design, being determined that the best conditions for the production of the enzyme were $3 \mathrm{~g}$ of substrate, 50\% moisture and temperature of $25^{\circ} \mathrm{C}$. Other authors reported enzyme production by Mucor spp. in SSF using wheat bran mixture was optimal at $30^{\circ} \mathrm{C}$ [11] [32]. Agrawal et al. [33] showed that most fungi have an optimum temperature for protease production by SSF between $28^{\circ} \mathrm{C}$ to $30^{\circ} \mathrm{C}$ unlike the optimal conditions obtained in this work show a better enzyme production at $25^{\circ} \mathrm{C}$. The temperature in the solid state fermentation is an important factor for this type of fermentation is characterized by being exothermic, or large amounts of heat are released, which are directly proportional to the metabolic activity of the micro-organism, especially fermentations by filamentous fungi where the temperature directly influences the spore germination, growth and product formation.

The statistical analysis showed that all variables were significant with variance analysis ANOVA with confidence level 95\% ( $p \leq 0.05$ ) (Figure 1). However, the variable temperature was the statistically most significant showing a negative effect. The decrease of temperature indicated a greater enzyme production by the microorganism. The temperature is essential in metabolic regulation and in the enzyme synthesis [34]-[36].

The moisture demonstrated a positive effect (Figure 1). The moisture studies in this type of fermentation allow studying the reduction of the risk of contamination. Furthermore, a study with adequate moisture for its substrate allows the formation of a water film on the surface, to facilitate dissolution and transfer of nutrients and oxygen. High moisture level tends to increased enzyme production, which may be due a rise in the substrate porosity that allows for a better oxygen transfer favoring the development of the microorganism [37]. The optimal value for moisture (50\%) was in accordance with that reported by Chutmanop et al. [38] for the production of proteases by Aspergillus oryzae (Ozykat-1) using wheat bran and rice bran as substrate. Thanapimmetha et al. [39] also showed similar results, with an optimum value of $45 \%$ for the production of protease in solid-state fermentation using Jatropha curcas as residue. 


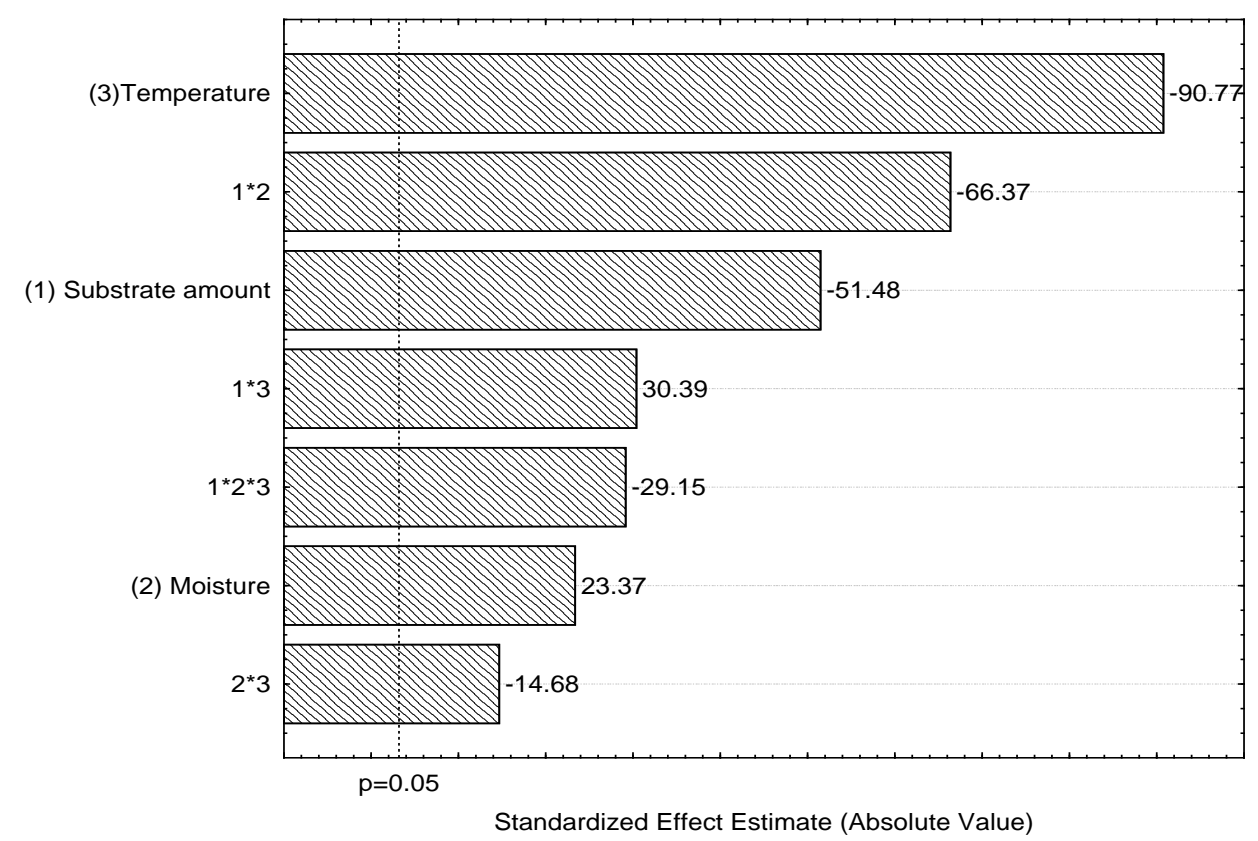

Figure 1. Pareto chart of variables effects in fibrinolytic activity (U/mL) produced by Mucor subtillissimus UCP 1262 in solid-state fermentation using wheat bran as substrate after 72 hours fermentation. PA: Protease activity.

Table 3. Production of fibrinolytic proteases by Mucor subtillissimus UCP 1262 using a $2^{3}$ factorial design.

\begin{tabular}{cccccccc}
\hline & \multicolumn{3}{c}{ Variables } \\
\cline { 2 - 9 } & Substrate amount (g) & Moisture (\%) & Temperature $\left({ }^{\circ} \mathrm{C}\right)$ & PA $(\mathrm{U} / \mathrm{mL})$ & U/gds & FA $(\mathrm{U} / \mathrm{mL})$ & U/gds \\
\hline 1 & 3 & 30 & 25 & 36.20 & 440.74 & 106.66 & 799.95 \\
2 & 7 & 30 & 25 & 27.23 & 316.62 & 84.16 & 631.20 \\
3 & 3 & 50 & 25 & 48.33 & 801.93 & 144.58 & 1084.35 \\
4 & 7 & 50 & 25 & 47.90 & 644.97 & 84.58 & 634.35 \\
5 & 3 & 30 & 35 & 26.26 & 223.29 & 38.33 & 287.47 \\
6 & 7 & 30 & 35 & 23.36 & 218.72 & 75.83 & 568.72 \\
7 & 3 & 50 & 35 & 45.83 & 668.72 & 90.83 & 681.22 \\
8 & 7 & 50 & 35 & 38.66 & 569.64 & 32.08 & 240.60 \\
$9 \mathrm{C}$ & 5 & 40 & 30 & 35.56 & 456.67 & 79.16 & 593.70 \\
$10 \mathrm{C}$ & 5 & 40 & 30 & 36.20 & 465.69 & 80.41 & 603.07 \\
$11 \mathrm{C}$ & 5 & 40 & 30 & 22.43 & 253.73 & 80.00 & 600.00 \\
$12 \mathrm{C}$ & 5 & 40 & 29.16 & 367.56 & 80.83 & 606.22 \\
\hline
\end{tabular}

U/gdb: Unit/gram of substrate on a dry basis; PA: Protease activity; FA: Fibrinolytic activity; C: Central points.

\subsection{Amidolytic Activity}

The crude extract produced by $M$. subtilissimus exhibited the highest activity against N-succinyl-Ala-AlaPro-Phe-pNa, a substrate for chymotrypsin, suggesting the presence of a chymotrypsin-like protease. The protease with fibrinolytic activity produced by Sugimato et al. [40] using Fusarium sp. BLB was also characterized as serine protease. Similar results were presented by Cordiceps militaris [41], Perennipiria fraxinea [41] and Armillaria mella [43]. 


\subsection{Effect of Temperature on Protease Activity and Stability}

The temperature is one of the most critical parameters to be controlled in bioprocesses [30]. As shown in Figure 2 M. subtillissimus UCP 1262 extract exhibited an optimum temperature for protease activity at $45^{\circ} \mathrm{C}$. A similar value $45^{\circ} \mathrm{C}$ was obtained for proteases from Colletotrichum gloeosporioides [44], Rhizopus chinenesis 12 [45], Schizophyllum commune [7] and Myceliophthora sp. [46] while $50^{\circ} \mathrm{C}$ was the optimal for Trichoderma reesei QM9414 [47] and Fusarium culmorum [48]. The protease from M. subtillissimus UCP 1262 M. retained 75.52\% of its original activity after being subjected to $45^{\circ} \mathrm{C}$ for $120 \mathrm{~min}$ (Figure 3), presenting a higher stability than the enzyme reported by Zanphorlin et al. [49]. That maintained $95 \%$ of the maximum activity at $60^{\circ} \mathrm{C}$. No protease activity was detected after heating the enzyme at $100^{\circ} \mathrm{C}$ for $15 \mathrm{~min}$.

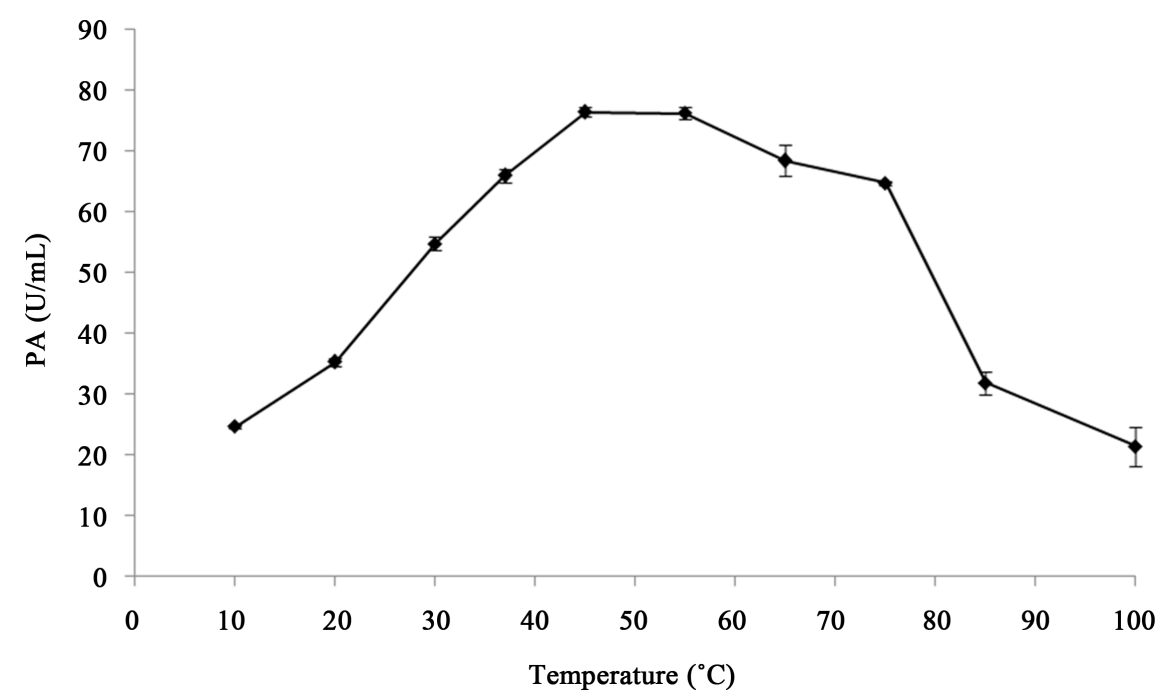

Figure 2. Effect of temperature on protease produced by Mucor subtillissimus UCP 1262 in solid-state fermentation using wheat bran as substrate after 72 hours fermentation. PA: Protease activity.

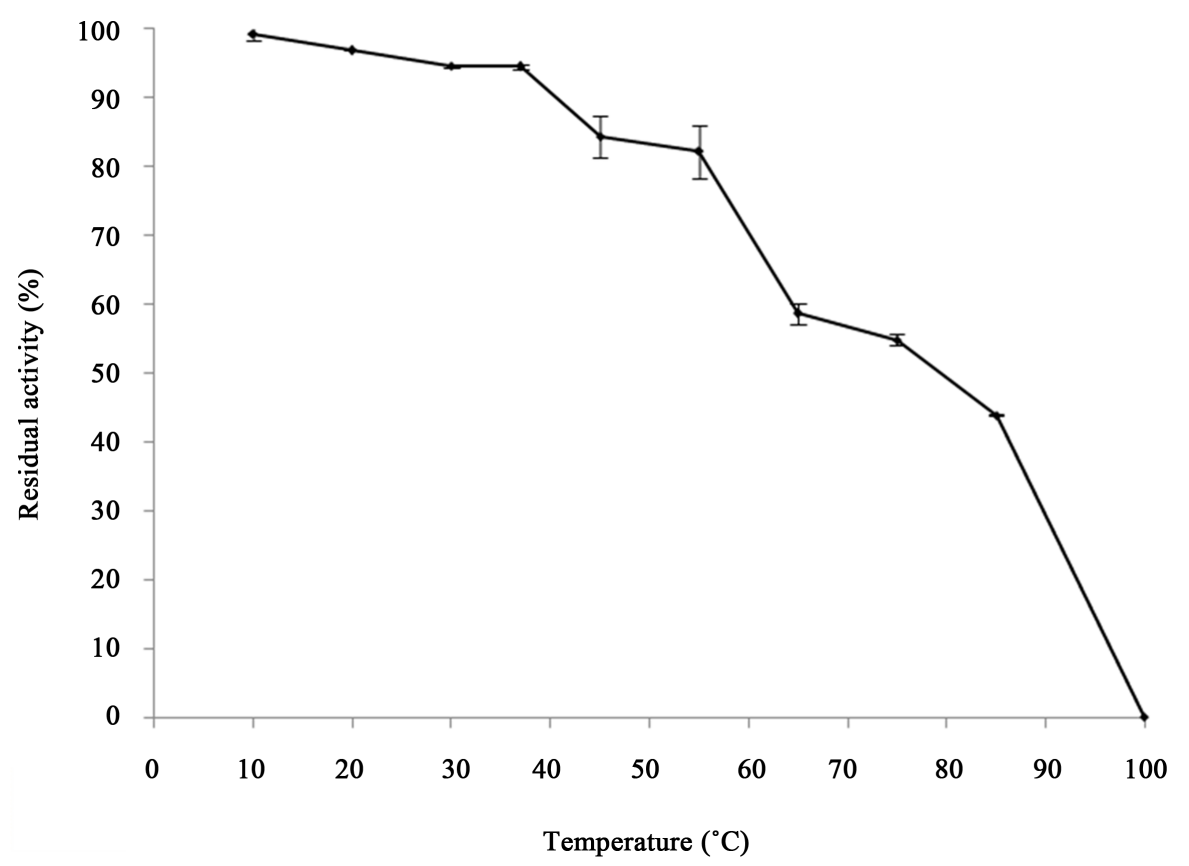

Figure 3. Stability of protease produced by Mucor subtillissimus UCP 1262 by solid-state fermentation at $45^{\circ} \mathrm{C}$ after $120 \mathrm{~min}$. 


\subsection{Effect of Metal Ions on Protease Activity}

It was found that the addition of the ions $\mathrm{K}^{+}, \mathrm{Mn}^{2+}, \mathrm{Ca}^{2+}$, increased protease activity at all concentrations used, while a reduction was observed when $\mathrm{Zn}^{2+}$ and $\mathrm{Co}^{2+}$ were added at concentrations of $5 \mathrm{mM}$ and $10 \mathrm{mM}, \mathrm{Cu}^{2+}$ ions had a negative effect on enzyme activity for all concentrations tested (Table 4).

The activity of protease produced by Ulocladium botrytis using solid-state fermentation [50] was inhibited in the presence of $\mathrm{Zn}^{+}$or $\mathrm{Cu}^{2+}$ and increased significantly in the presence of $\mathrm{Ca}^{2+}, \mathrm{Mg}^{2+}$, and $\mathrm{K}^{+}$. The increase of protease activity may be due metallic ions that link the substrate and enzyme, and that ion keep the substrate in active site of the enzyme [50] [51].

\subsection{Effect of Inhibitors in Protease Activity}

The enzyme activity was significantly inhibited by PMSF (81\%) and not by any other inhibitor (Table 5) which was validated by the Student's t-test. These results demonstrate that the enzyme is a serine protease. Also, the activity of the protease produced by Penicillium sp. using SSF was 93\% inhibited by PMSF [10]. Zanphorlin et al. [46] also obtained through SSF by the thermophilic fungus Myceliophthora sp. a protease that was completely inhibited by PMSF.

\section{Conclusion}

In conclusion, a new protease was produced by Mucor subtillissimus UCP 1262 using wheat bran as substrate in SSF. Inhibition studies and high specificity to N-succinyl-Ala-Ala-Pro-Phe- $p N a$ indicate that it is a chymotrypsin-like serine protease. The enzyme exhibited stability over a wide range of temperature values. Further studies will be made to the purification of the enzyme.

Table 4. Effect of metal ions on protease activity.

\begin{tabular}{cccc}
\hline & & Residual activity (\%) & $10 \mathrm{mM}$ \\
\hline Ions & $2.5 \mathrm{mM}$ & $5 \mathrm{mM}$ & 100.0 \\
\cline { 2 - 4 } & 100.0 & 100.0 & 106.7 \\
$\mathrm{~K}^{+}$ & $130.0^{*}$ & $133.9^{*}$ & 116.1 \\
$\mathrm{Ca}^{+}$ & $123.1^{*}$ & $124.8^{*}$ & 110.4 \\
$\mathrm{Mn}^{+}$ & 109.3 & 104.3 & 85.8 \\
$\mathrm{Zn}^{+}$ & $108.4^{*}$ & 98.7 & 96.5 \\
$\mathrm{Mg}^{+}$ & 103.8 & 102.9 & 84.5 \\
$\mathrm{Co}^{+}$ & 101.1 & 91.9 & $64.5^{*}$ \\
$\mathrm{Cu}^{+}$ & $85.7^{*}$ & $78.2^{*}$ & 107.1 \\
$\mathrm{Fe}^{+}$ & 101.3 & 80.7 & 115.7 \\
$\mathrm{Na}^{+}$ & 89.8 & 94.4 & \\
\hline
\end{tabular}

*Student $\mathrm{t}$ test for independent samples; ${ }^{*} p \leq 0.05$.

Table 5. Effect of inhibitors on protease activity.

\begin{tabular}{cc}
\hline Inhibitors & Residual activity (\%) \\
\hline Control & 100.0 \\
EDTA & $90.9^{*}$ \\
B-Mercaptoethanol & $93.4^{*}$ \\
PMSF & $18.4^{*}$ \\
Pepstatin A & 98.9 \\
Iodoacetic acid & 97.6 \\
\hline
\end{tabular}

*Student t test for independent samples; ${ }^{*} p \leq 0.05$. 


\section{Acknowledgements}

The authors wish to acknowledge the financial support from CAPES (Coordenação de Aperfeiçoamento de Pessoal de Nível Superior, Brasília, Brasil), FACEPE (Fundação de Amparo à Ciência e Tecnologia do Estado de Pernambuco, Recife, Brasil) and the CNPq (Conselho Nacional de Desenvolvimento Científico e Tecnológico, Brasília, Brasil). The authors wish to thank the project was approved in network RENNORFUN Notice MCT/CNPq/MMA/MEC/CAPES/FNDCT. Ação Transversal/FAPs n.47/2010, Sistema Nacional de Pesquisa em Biodiversidade-SISBIOTA/Brasil.

\section{References}

[1] Mine, Y., Kwan, W.A.H. and Jiang, B. (2005) Fibrinolytic Enzymes in Asian Traditional Fermented Foods. Food Research International, 38, 243-250. http://dx.doi.org/10.1016/j.foodres.2004.04.008

[2] Mukherjee, A.K., Rai, S.K., Thakur, R., Chattopadhyay, P. and Kar, S.K. (2012) Bafibrinase: A Non-Toxic, NonHemorrhagic, Direct-Acting Fibrinolytic Serine Protease from Bacillus sp. Strain AS-S20-I Exhibits in Vivo Anticoagulant Activity and Thrombolytic Potency. Biochimie, 94, 1300-1308. http://dx.doi.org/10.1016/j.biochi.2012.02.027

[3] Simkhada, J.R., Mander, P., Cho, S.S. and Yoo, J.C. (2010) A Novel Fibrinolytic Protease from Streptomyces sp. CS684. Process Biochemistry, 45, 88-93. http://dx.doi.org/10.1016/j.procbio.2009.08.010

[4] Montriwong, A., Kaewphuak, S., Rodtong, S., Roytrakul, S. and Yongsawatdigul, J. (2012) Novel Fibrinolytic Enzymes from Virgibacillus halodenitrificans SK1-3-7 Isolated from Fish Sauce Fermentation. Process Biochemistry, 47, 2379-2387. http://dx.doi.org/10.1016/j.procbio.2012.09.020

[5] Banerjee, S., Prasanna, R. and Bagchi, S.N. (2013) Purification and Characterization of a Fibrino(geno)lytic Protease from Cultured Natural Isolate of a Cyanobacterium, Anabaena fertilissima. Journal of Applied Psychology, 25, 11111122. http://dx.doi.org/10.1007/s10811-012-9946-6

[6] Chang, C.T., Wang, P.M., Hung, Y.F. and Chung, Y.C. (2012) Purification and Biochemical Properties of a Fibrinolytic Enzyme from Bacillus subtilis-Fermented Red Bean. Food Chemistry, 133, 1611-1617. http://dx.doi.org/10.1016/j.foodchem.2012.02.061

[7] Lu, C.L., Chen, S. and Chen, S.N. (2010) Purification and Characterization of a Novel Fibrinolytic Protease from Schizophyllum commune. Food Drug Analysis, 18, 69-76.

[8] Medeiros Silva, G.M., Marques, D.A.V., Porto, T.S., Lima-Filho, J.L., Teixeira, J.A.C., Pessoa-Júnior, A. and Porto, A.L.F. (2013) Extraction of Fibrinolytic Proteases from Streptomyces sp. DPUA1576 Using PEG-Phosphate Aqueous Two-Phase Systems. Fluid Phase Equilibria, 339, 52-57. http://dx.doi.org/10.1016/j.fluid.2012.11.033

[9] Shirasaka, N., Naitou, M., Okamura, K., Kusuda, M., Fukuta, Y. and Terashita, T. (2012) Purification and Characterization of a Fibrinolytic Protease from Aspergillus oryzae KSK-3. Mycoscience, 53, 354-364. http://dx.doi.org/10.1007/S10267-011-0179-3

[10] Germano, S., Pandey, A., Osaku, C.A., Rocha, S.N. and Soccol, C.R. (2003) Characterization and Stability of Proteases from Penicillium sp. Produced by Solid-State Fermentation. Enzyme and Microbial Technology, 32, $246-251$. http://dx.doi.org/10.1016/S0141-0229(02)00283-1

[11] Yegin, S., Fernandez-Lahore, M., Salgado, A.J.L., Guvenc, U., Goksungur, Y. and Tari, C. (2011) Aspartic Proteinases from Mucor spp. in Cheese Manufacturing. Applied Microbiology and Biotechonology, 89, 949-960. http://dx.doi.org/10.1007/s00253-010-3020-6

[12] Pandey, A., Soccol, C.R., Nigam, P., Brand, D., Mohanb, R. and Roussos, S. (2000) Biotechnological Potential of Coffee Pulp and Coffee Husk for Bioprocesses. Biochemical Engineering Journal, 6, 153-162. http://dx.doi.org/10.1016/S1369-703X(00)00084-X

[13] Banerjee, R., Mukherjee, G. and Patra, K.C. (2005) Microbial Transformation of Tannin-Rich Substrate to Gallic Acid through Co-Culture Method. Bioresource Technology, 96, 949-953. http://dx.doi.org/10.1016/j.biortech.2004.08.004

[14] Certik, M. and Adamechova, Z. (2009) Cereal-Based Bioproducts Containing Polyunsaturated Fatty Acids. Lipid Technology, 21, 11-12. http://dx.doi.org/10.1002/lite.200900058

[15] Fernandez-Lahore, H.M., Fraile, E.R. and Cascone, O. (1998) Aspartic Proteinase Recovery from Solid-State Fermentation System. Journal Biotechnology, 62, 83-93. http://dx.doi.org/10.1016/S0168-1656(98)00048-0

[16] Barrios-González, J. (2012) Solid-State Fermentation: Physiology of Solid Medium, Its Molecular Basis and Applications. Process Biochemistry, 47, 175-185. http://dx.doi.org/10.1016/j.procbio.2011.11.016

[17] Ginther, C.L. (1979) Sporulation and the Production of Serine Protease and Cephamycin C by Streptomyces lactamdurans. Antimicrobial Agents and Chemotherapy, 15, 522-526. http://dx.doi.org/10.1128/AAC.15.4.522

[18] Wang, S.L., Wu, Y.Y. and Liang, T.W. (2011) Purification and Biochemical Characterization of a Nattokinase by 
Conversion of Shrimp Shell with Bacillus subtilis TKU007. New Biotechnology, 28, 196-202. http://dx.doi.org/10.1016/j.nbt.2010.09.003

[19] Bradford, M.M. (1976) A Rapid and Sensitive Method for the Quantitation of Microgram Quantities of Protein Utilizing the Principle of Protein-Dye Binding. Analytical Biochemistry, 72, 248-254. http://dx.doi.org/10.1016/0003-2697(76)90527-3

[20] Kim, W., Choi, K., Kim, Y., Park, H., Choi, J., Lee, Y., Oh, H., Kwon, I. and Lee, S. (1996) Purification and Characterization of a Fibrinolytic Enzyme Produced from Bacillus sp. Strain CK 11-4 Screened from Chungkook-Jang. Applied Environmental Microbiology, 62, 2482-2488.

[21] Statsoft Inc. Statistica (Data Analysis Software Systems) Version 8.0, 2008.

[22] Oliveira, L.F., Nascimento, M.R.F., Borges, S.V., Ribeiro, P.C.N. and Ruback, V.R. (2002) Aproveitamento alternativo da casca de maracujá-amarelo (Passiflora edulis F. Flavicarpa) para produção de doce em calda. Ciencia e Tecnologia de Alimentos, 22, 259-262. http://dx.doi.org/10.1590/S0101-20612002000300011

[23] Aguiar, T.M., Rodrigues, F.S., Santos, E.R. and Sabaa-Srur, A.U.O. (2010) Caracterização química e avaliação do valor nutritivo de sementes de acerola. Journal of the Brazilian Society for Food and Nutrition, 35, 91-102.

[24] Henrique, W., Sampaio, A.A.M., Leme, P.R., Alleoni, G.F., Lanna, D.P.D. and Malheiros, E.B. (2003) Digestibilidade e Balanço de Nitrogênio em Ovinos Alimentados à Base de Dietas com Elevado Teor de Concentrado e Níveis Crescentes de Polpa Cítrica Peletizada. Revista Brasileira de Zootecnia, 32, 2007-2015. http://dx.doi.org/10.1590/S1516-35982003000800026

[25] Ravikumar, G., Gomathi, D., Kalaiselvi, M. and Uma, C. (2012) A Protease from the Medicinal Mushroom Pleurotus sajor-caju; Production, Purification and Partial Characterization. Asian Pacific Journal Tropical Biomedicine, 2, S411S417. http://dx.doi.org/10.1016/s2221-1691(12)60198-1

[26] Silveira, C.M. and Furlong, E.B. (2007) Caracterização de compostos nitrogenados presentes em farelos fermentados em estado sólido. Ciencia e Tecnologia de Alimentos, 27, 805-811. http://dx.doi.org/10.1590/S0101-20612007000400021

[27] Haltrich, D., Nidetzky, B., Kulbe, K.D., Steiner, W. and Zupan, S. (1996) Production of Fungal Xylanases. Bioresource Technology, 58, 137-161. http://dx.doi.org/10.1016/S0960-8524(96)00094-6

[28] Alves, M.H., Campos-Takaki, G.M., Okada, K., Pessoa, I.H.F. and Milanez, A.I. (2005) Detection of Extracellular Protease in Mucor Species. Revista Ibero Americana de Micologia, 22, 114-117. http://dx.doi.org/10.1016/S1130-1406(05)70020-6

[29] Alves, M.H., Campos-Takaki, G.M., Porto, A.L.F. and Milanez, A.I. (2002) Screening of Mucor spp. for the Production of Amylase, Lipase, Polygalacturonase and Protease. Brazilian Journal of Microbiology, 33, 325-330. http://dx.doi.org/10.1590/S1517-83822002000400009

[30] Sathya, R., Pradeep, B.V., Angayarkann, J. and Palaniswamy, M. (2009) Production of Milk Clotting Protease by a Local Isolate of Mucor circinelloides under SSF Using Agro-Industrial Wastes. Biotechnology Bioprocess Engineering, 14, 788-794. http://dx.doi.org/10.1007/s12257-008-0304-0

[31] Soares, F.E.F., Braga, F.R., Araújo, J.V., Geniêr, H.L.A., Gouveia, A.S. and Queiroz, J.H. (2013) Nematicidal Activity of Three Novel Extracellular Proteases of the Nematophagous Fungus Monacrosporium sinense. Parasitology Research, 112, 1557-1565. http://dx.doi.org/10.1007/s00436-013-3304-8

[32] Tubesha, Z.A. and Al-Delaimy, K.S. (2003) Rennin-Like Milk Coagulant Enzyme Produced by Local Isolate of Mucor. International Journal of Dairy Technology, 56, 237-241. http://dx.doi.org/10.1046/j.1471-0307.2003.00113.x

[33] Agrawal, D., Patidar, P., Banerjee, T. and Patil, S. (2004) Production of Alkaline Protease by Penicillium sp. under SSF Conditions and Its Application to Soy Protein Hydrolysis. Process Biochemistry, 39, 977-998. http://dx.doi.org/10.1016/S0032-9592(03)00212-7

[34] Calık, P., Calık, G. and Ozdamar, T.H. (2001) Bioprocess Development for Serine Alkaline Protease Production: A Review. Reviews in Chemical Engineering, 17, 1-62. http://dx.doi.org/10.1515/REVCE.2001.17.S1.1

[35] Ito, K., Kawase, T., Sammoto, H., Gomi, K., Kariyama, M. and Miyake, T. (2011) Uniform Culture in Solid-State Fermentation with Fungi and Its Efficient Enzyme Production. Journal of Bioscience and Bioengineering, 3, 300-305. http://dx.doi.org/10.1016/j.jbiosc.2010.11.008

[36] Bhunia, B., Basak, B. and Dey, A. (2012) A Review on Production of Serine Alkaline Protease by Bacillus spp. Journal of Biochemical Technology, 3, 448-457.

[37] Delabona, P.S., Pirota, R.D.P.B., Codima, C.A., Tremacoldi, C.R., Rodrigues, A.F. and Cristiane, S. (2013) Effect of Initial Moisture Content on Two Amazon Rainforest Aspergillus Strains Cultivated on Agro-Industrial Residues: Biomass-Degrading Enzymes Production and Characterization. Industrial Crops and Products, 42, 236-242. http://dx.doi.org/10.1016/j.indcrop.2012.05.035 
[38] Chutmanop, J., Chuichucherm, S., Chisti, Y. and Srinophakun, P. (2008) Protease Production by Aspergillus oryzae in Solid-State Fermentation Using Agroindustrial Substrates. Journal of Chemical Technology and Biotechnology, 83, 1012-1018. http://dx.doi.org/10.1002/jctb.1907

[39] Thanapimmethaa, A., Luadsongkrama, A., Titapiwatanakunc, B. and Srinophakun, P. (2012) Value Added Waste of Jatropha curcas Residue: Optimization of Protease Production in Solid-State Fermentation by Taguchi DOE Methodology. Industrial Crops and Products, 37, 1-5. http://dx.doi.org/10.1016/j.indcrop.2011.11.003

[40] Sugimato, S., Fugii, T., Moriymio, T., Johodo, T. and Nakamura, T. (2007) The Fibrinolytic Activity of a Novel Protease Derived from a Tempeh Producing Fungus, Fusarium sp. Bioscience, Biotechnology and Biochemistry, 71, 21842189. http://dx.doi.org/10.1271/bbb.70153

[41] Choi, D., Cha, W.S. and Park, N. (2011) Purification and Characterization of a Novel Fibrinolytic Enzyme from Fruiting Bodies of Korean Cordyceps militaris. Bioresource Techonology, 102, 3279-3285. http://dx.doi.org/10.1016/j.biortech.2010.10.002

[42] Kim, J.S., Kim, J.E. and Choi, B.S. (2008) Purification and Characterization of Fibrinolytic Metalloprotease from Perenniporia fraxinea Mycelia. Mycological Research, 112, 990-998. http://dx.doi.org/10.1016/j.mycres.2008.01.029

[43] Lee, S.Y., Kim, J.S. and Kim, J.E. (2005) Purification and Characterization of Fibrinolytic Enzyme from Cultured Mycelia of Armillaria mellea. Protein Expression and Purification, 43, 10-17. http://dx.doi.org/10.1016/j.pep.2005.05.004

[44] Dunaevsky, Y.E., Matveeva, A.R., Beliakova, G.A., Domash, V.I. and Belozersky, M.A. (2007) Extracellular Alkaline Proteinase of Colletotrichum gloeosporioides. Biochemistry, 72, 345-350. http://dx.doi.org/10.1134/s0006297907030145

[45] Kirk, P.M., Cannon, P.F., David, J.C. and Stalpers, J.A. (2001) Ainsworth \& Bisby’s Dictionary of the Fungi. 9th Edition, CAB International, Oxon, 452.

[46] Zanphorlin, L.M., Cabral, H., Arantes, E., Assis, D., Juliano, L., Juliano, M.A., Silva, R., Gomes, E. and BonillaRodriguez, G.O. (2011) Purification and Characterization of a New Alkaline Serine Protease from the Thermophilic Fungus Myceliophthora sp. Process Biochemistry, 46, 2137-2143. http://dx.doi.org/10.1016/j.procbio.2011.08.014

[47] Dienes, D., Borjesson, J., Hagglund, P., Tjerneld, F., Liden, G. and Reczey, K. (2007) Identification of a Trypsin-Like Serine Protease from Trichoderma reesei QM9414. Enzyme Microbiology and Technology, 40, 1087-1094. http://dx.doi.org/10.1016/j.enzmictec.2006.08.013

[48] Pekkarinen, A., Mannonen, L., Jones, B.L. and Niku-Paavola, M.L. (2000) Production of Proteases by on Barley Grains and in Media Containing Cereal Fusarium Species Grown Proteins. Journal of Ceramic Science, 31, $253-261$. http://dx.doi.org/10.1006/jcrs.2000.0305

[49] Zanphorlin, L.M., Facchini, F.D.A., Vasconcelos, F., Bonugli-Santos, R.C., Rodrigues, A., Sette, L.D., Gomes, E. and Bonilla-Rodriguez, G.O. (2010) Production, Partial Characterization and Immobilization in Alginate Beads of an Alkaline Protease from a New Thermophilic Fungus Myceliophthora sp. The Journal of Microbiology, 48, 331-336. http://dx.doi.org/10.1007/s12275-010-9269-8

[50] Heba, I., Abo-Elmagd, A. and Housseiny, M.M. (2012) Purification and Characterization of Carboxymethyl Cellulase and Protease by Ulocladium botrytis Preuss ATCC 18042 Using Water Hyacinth as a Substrate under Solid-State Fermentation. Annals of Microbiology, 62, 1547-1556. http://dx.doi.org/10.1007/s13213-011-0409-0

[51] Roy, S.K., Dey, S.K., Raha, S.K. and Chakrabatry, S.L. (1990) Purification and Properties of an Extracellular Endoglucanase from Myceliophthora thermophila. Journal of General Microbiology, 136, 1967-1971. http://dx.doi.org/10.1099/00221287-136-10-1967 